\section{Caveats in treating thyroid disease: practical implications}

\author{
G I Varughese ${ }^{1} \quad$ A A Tahrani ${ }^{1} \quad$ J Davis $^{2}$ \\ R N Clayton ${ }^{1} \quad$ F W F Hanna ${ }^{1}$
}

J R Soc Med 2006;99:582-583

\section{KEY MESSAGE}

The timing of treatment in patients with thyroid disease is extremely important. This Grand Round reminds clinicians to be aware of unusual causes for persistent abnormalities in thyroid function tests (TFTs) despite optimal treatment.

\section{CASE HISTORY}

This case concerns a 47-year-old woman who was initially diagnosed as having primary hypothyroidism nearly four years prior to this incident; on treatment with levothyroxine sodium $\left(\mathrm{LT}_{4}\right) 150 \mu \mathrm{g}$ daily. Despite reasonable doses of $\mathrm{LT}_{4}$, and being fully compliant with her therapy, at no stage was her TSH less than $20 \mathrm{mU} / \mathrm{L}$ (Table 1). Malabsorption was ruled out and there were no clinical features to suggest this. When the patient was reviewed in the endocrine clinic, she was advised to take the tablets on an empty stomach (rather than with the white tea and breakfast that she had regularly been having immediately following her $\mathrm{LT}_{4}$ tablets). On subsequent follow-up four months later, the TFTs had improved on the same dose of $\mathrm{LT}_{4}$ and she had lost nearly $2 \mathrm{~kg}$ in weight despite the 'Christmas Effect', as she described it, and she felt well in herself. Subsequent TFTs continue to remain in the reference range with the altered timing of intake of $\mathrm{LT}_{4}$.

\section{COMMENT}

Prior to giving her the advice to make alterations to the timing of tablets, her TFTs showed consistently low free thyroxine (T4) and correspondingly high thyroid stimulating hormone (TSH) concentrations, respectively (Table 1). According to the drug information leaflet of $\mathrm{LT}_{4}$, the recommendation is to take the tablets preferably before breakfast. Ideally, the tablets should be taken on an empty stomach, as the sodium salt enhances the absorption

Departments of Endocrinology ${ }^{1}$ \& Medicines Information ${ }^{2}$ (Pharmacy), University Hospital of North Staffordshire, Stoke-on-Trent ST4 6QG, UK
Table 1 Thyroid function over the years

\begin{tabular}{lll}
\hline Year & TSH (0.3-5.0 $\mathbf{~} \boldsymbol{U} / \mathbf{L})$ & $\mathbf{T 4}(\mathbf{1 0 - 2 2} \mathbf{~ p m o l / L )}$ \\
\hline April 2006 & 2.2 & 18 \\
December 2005 & 2.87 & 15 \\
August 2005 & 20.18 & 10 \\
April 2003 & 24.25 & 13 \\
October 2002 & 20.77 & 11 \\
May 2002 & 31.04 & 14 \\
February 2002 & 50.05 & 11 \\
\hline
\end{tabular}

of levothyroxine, which is greater in the fasting than in the fed state. ${ }^{1,2}$ Gastrointestinal absorption of $\mathrm{LT}_{4}$ is on average $80 \%,{ }^{3}$ mainly from the small intestine. ${ }^{4}$ Interestingly, nonspecific absorption of $\mathrm{LT}_{4}$ by dietary fibres has been shown to decrease the bioavailability of $\mathrm{LT}_{4}$, necessitating a higher dose in patients with a high intake of dietary fibre (e.g. wholewheat bread, bran, granola). ${ }^{5}$ Of note, administration of $\mathrm{LT}_{4}$ concurrently with soya dietary protein has also resulted in decreased absorption of $\mathrm{LT}_{4}$ and the need for higher oral doses of $\mathrm{LT}_{4}$ to attain therapeutic serum thyroid hormone levels. ${ }^{6}$ Formulations containing soy milk were recognized as affecting thyroid function in infants nearly half a century ago ${ }^{7,8}$ and emphasis has been reiterated on this topic more recently. ${ }^{9}$

The timing of treatment in patients with thyroid disease is extremely important and should be explored in detail when TFTs fail to improve despite therapy. The patient described above was not on any other medication that would have interfered with the bioavailability or pharmacokinetics of $\mathrm{LT}_{4}$. Since factors affecting the management of thyroid dysfunction - such as those detailed in Table 2-are infrequently encountered in clinical practice, patient noncompliance may be suspected; we suggest that an alternative cause should be considered in such patients.

Competing interests None declared.

Guarantor F W F Hanna.

\section{REFERENCES}

1 DeGroot LJ, Jameson JL. Hypothyroidism and Myxedema Coma. In: Endocrinology: Volume 2. 4th edn. Philadelphia: WB Saunders Company, 2001; Chapter 105: pp 1500-1

2 Greenspan FS, Gardner DG. The Thyroid Gland. In: Basic and Clinical Endocrinology. Maidenhead, UK: McGraw-Hill Companies, 2004; Chapter 7: pp 215

3 Fish LH, Schwartz HL, Cavanaugh J, Steffes MW, Bantle JP, Oppenheimer JH. Replacement dose, metabolism, and bioavailability 
Table 2 Various drugs and conditions causing hypothyroidism in patients on thyroxine

\begin{tabular}{|c|c|}
\hline Cause of hypothyroidism & Reference \\
\hline \multicolumn{2}{|l|}{ Impaired absorption of thyroxine } \\
\hline Dietary Fibre (wholewheat bread, granola, bran) & Liel Y et al. J Clin Endocrinol Metab 1996;81:857-9 \\
\hline Bile acid sequestering agents & $\begin{array}{l}\text { Witztum JL et al. J Clin Endocrinol Metab 1978;46:838-40 } \\
\text { Harmon SM et al. Ann Intern Med 1991;115:658-9 }\end{array}$ \\
\hline Sucralfate & Havranoka J et al. Ann Intern Med 1992;117:445-6 \\
\hline Aluminium Hydroxide & Sperber AD et al. Arch Intern Med 1992;152:183-4 \\
\hline Ferrous sulphate & Campbell NR et al. Ann Intern Med 1992;117:1010-3. \\
\hline Calcium Carbonate & Singh $\mathrm{N}$ et al. JAMA 2000;283:2822-5 \\
\hline Lithium & Kleiner J et al. J Clin Psychiatry 1999;60:249-55 \\
\hline Selenium deficiency & Moncayo R et al. Clin Nutr 2005;24:530-1 \\
\hline Omeprazole & Centanni M et al. NEJM 2006;354:1787-95 \\
\hline Bone Marrow Transplantation & Carlson K et al. Bone Marrow Transplant 1992;10:123-7 \\
\hline Herbal remedies & Geatti O et al. Thyroidology 1993;5: 97-102 \\
\hline Soy & $\begin{array}{l}\text { Bell DS \& Ovalle F. Endocr Pract 2001;7:193-4 } \\
\text { Van Wyk JJ et al. Pediatrics 1959;24:752-60 } \\
\text { Hydovitz JD. NEJM 1960;262:351-3 } \\
\text { Conrad SC et al. Arch Dis Child 2004;89:37-40 }\end{array}$ \\
\hline Malabsorption \& short-bowel syndrome & Topliss DJ et al. Can Med Assoc J 1980;123:765-6 \\
\hline \multicolumn{2}{|l|}{ Increased clearance of thyroxine } \\
\hline Phenobarbital & Isley WL. Ann Intern Med 1987;107:517-8 \\
\hline Phenytoin & Isley WL. Ann Intern Med 1987;107:517-8 \\
\hline Carbamazepine & Isley WL. Ann Intern Med 1987;107:517-8 \\
\hline Rifampicin & Isley WL. Ann Intern Med 1987; 107:517-8 \\
\hline \multicolumn{2}{|l|}{ Increased need for thyroxine } \\
\hline Pregnancy & Mandel SJ et al. NEJM 1990;323:91-6 \\
\hline Weight gain & Glinoer D et al. J Clin Endocrinol Metab 1990;71:276-87 \\
\hline \multicolumn{2}{|l|}{ Other mechanisms } \\
\hline Amiodarone & Figge $\mathrm{J}$ et al. Ann Intern Med 1990;113:553-5 \\
\hline Raloxifene & Siraj ES et al. Arch Intern Med 2003;163:1367-70 \\
\hline Sertraline & McCowen KC et al. NEJM 1997;337:1010-1 \\
\hline Chloroquine & Munera Y et al. BMJ 1997;314:1593 \\
\hline Noncompliance with treatment & Ain KB et al. JAMA 1991;266:2118-20 \\
\hline
\end{tabular}

of levothyroxine in the treatment of hypothyroidism. Role of triiodothyronine in pituitary feedback in humans. N Engl J Med 1987; 316:764-70

4 Topliss DJ, Wright JA, Volpe R. Increased requirement for thyroid hormone after a jejunoileal bypass operation. Can Med Assoc J 1980; 123:765-6

5 Liel Y, Harman-Boehm I, Shany S. Evidence for a clinically important adverse effect of fiber-enriched diet on the bioavailability of levothyroxine in adult hypothyroid patients. J Clin Endocrinol Metab 1996;81:857-9
6 Bell DS, Ovalle F. Use of soy protein supplement and resultant need for increased dose of levothyroxine. Endocr Pract 2001;7:193-4

7 Van Wyk JJ, Arnold MB, Wynn J, Pepper F. The effects of a soybean product on thyroid function in humans. Pediatrics 1959;24:752-60

8 Hydovitz JD. Occurrence of goiter in an infant on a soy diet. $N$ Engl J Med 1960;262:351-3

9 Conrad SC, Chiu H, Silverman BL. Soy formula complicates management of congenital hypothyroidism. Arch Dis Child 2004;89:37-40 